\title{
Wujud Kebertahanan Kampung Kota Surabaya pada Masa Pandemi Covid 19
}

\author{
Eva Elviana $^{1 *}$, Diyan Lesmana ${ }^{2}$ \\ ${ }^{1}$ Permukiman Perkotaan, Arsitektur, Fakultas Arsitektur dan Desain, UPN "Veteran" Jawa Timur \\ ${ }^{2}$ Manajemen Konstruksi, Teknik Sipil, Fakultas Teknik, Universitas Narotama Surabaya \\ *Penulis Korespondensi: evaelviana.ar@upnjatim.ac.id; Telp.+62 81357931185
}

\begin{abstract}
Abstrak:
Keberadaan kampung-kampung sebagai area permukiman turut mengisi peruntukan tata guna lahan di kawasan perkotaan Surabaya. Kampung-kampung lama yang padat menempati area strategis diantara kawasan perdagangan dan jasa maupun peruntukan lainnya, mampu menunjukkan jati diri dan bertahan pada era perkembangan kota saat ini. Terlebih saat ini pada masa Pandemic Covid 19, sebagai kawasan permukiman yang berpenduduk padat, dituntut untuk dapat melindungi diri, baik dari sisi lingkungan fisik kampungnya maupun masyarakatnya, untuk mampu bertahan dalam situasi yang penuh keterbatasan. Penelitian ini bertujuan untuk mengungkap bagaimana perilaku masyarakat dalam lingkungan perkampungan di beberapa wilayah perkotaan, untuk dapat mampu bertahan, beradaptasi dan mengembangkan diri dalam menghadapi situasi pandemic Covid 19, yang serba terbatas dan tidak menentu. Masyarakat dituntut untuk mampu menyesuaikan diri dengan kondisi dan situasi yang telah mengubah kebiasaan sehari hari menjadi sebuah kebiasaan baru dalam era New Normal. Penelitian ini termasuk dalam kategori diskriptif kualitatif, yakni menganalisa kemampuan bertahan pada masyarakat di kampung kota, baik ditinjau dari aspek fisik lingkungannya maupun non fisik (perilaku \& budaya masyarakatnya), sehingga dapat dikaji wujud kebertahanannya. Metode penelitian menggunakan teknik observasi lapangan dan interview pada beberapa responden secara purpose sampling. Hasil dari penelitian ini menunjukkan bahwa kemampuan untuk bertahan, baik secara fisik maupun non fisik, akan mampu meningkatkan rasa memiliki terhadap tempat (sense of place).
\end{abstract}

Kata Kunci: aspek fisik dan non fisik; sense of place; wujud kebertahanan

\section{Latar Belakang}

Keberadaan kampung-kampung lama di kawasan perkotaan Surabaya, turut menghiasi tumbuh kembangnya kota Surabaya. Kawasan kampung lama, menempati area-area strategis diantara kawasan-kawasan perdagangan dan jasa, serta peruntukkan lainnya, mampu membentuk jati diri dalam memberikan identitas dan karakternya. Sebut saja kampong Peneleh, kampong Sutorejo, kampong Genteng Candirejo, kampong Ketandan, kampong Kebangsren, kampong Maspati, dan masih banyak kampong-kampong lainnya. Kampung-kampung lama tersebut tersebar di beberapa wilayah kota, dengan kondisi padat penghuninya.

Perkembangan dari masing-masing kampong tersebut membawa beberapa ciri atau karakter yang dapat menjadi identitas, sehingga memberikan sebuah keunikan tersendiri dalam mewarnai perkembangan kota. Mengutip dari Hastijanti (2020), beberapa ciri yang menunjukkan karakter sebuah kampong kota, antara lain:

1. Dari aspek Non Fisik (perilaku \& budaya masyarakatnya):

- Merupakan sebuah permukiman padat dengan karakter masyarakat yang heterogen

- Masyarakatnya memiliki interaksi social yang tinggi, dengan rasa kekerabatan yang cukup kental

- Memiliki hak historis terhadap wilayah atau teritorinya

2. Sedangkan dari aspek Fisik (lingkungannya), adalah:

- Memiliki akses yang kecil (micro mobility), sehingga layak disebut kampong. Dimana kendaraan yang melintas hanya dimungkinkan untuk yang roda dua/ tiga. Sedangkan roda empat tidak bisa melewatinya.

- Keterbatasan adanya ruang public (public space), yang dipakai sebagai tempat kegiatan masyarakat

\subsection{Visualisasi Kampung Kota Surabaya}

Pada era saat ini terjadi re-definisi pada sebuah istilah kampong. Dimana dalam perkembangannya, beberapa kampong kota Surabaya mampu menunjukkan eksistensi/jati diri dan kebertahanan sebagai kampong lama. Dengan menggali potensi masyarakat maupun lingkungannya, sehingga membentuk sebuah karakter dan dapat menjadi identitas dari masing-masing tempat atau lokasi. Masyarakat kampong kota berusaha mempertahankan tradisi dan seni budaya, yang diusung menjadi sebuah atraksi wisata yang menarik, layak jual, melalui promosi pada media social. Hal ini dapat memberikan corak dan ragam tersendiri, dalam upaya meningkatkan citra/ image kampong serta memberikan sense of place. Beberapa contoh perkembangan kampong kota, yang mampu memberikan 
identitas wilayah dengan keunikan penamaan atau sebutan, antara lain:

- Kampong Warna-warni di Kenjeran,

- Kampong Nelayan di Bulak,

- Kampong Budaya di Ketandan,

- Kampung Lawas Maspati,

- Kampung Kungfu di Kapasan,

- Kampung Sejarah di Peneleh

- Kampung Made di Lakarsantri

- Kampung Herbal di Candirejo

- dan lain sebagainya.

Beberapa gambar visualisasi kampong di Surabaya, ditunjukkan pada beberapa gambar berikut ini, sebagai upaya untuk memberikan identitas atau menunjukkan jati diri:
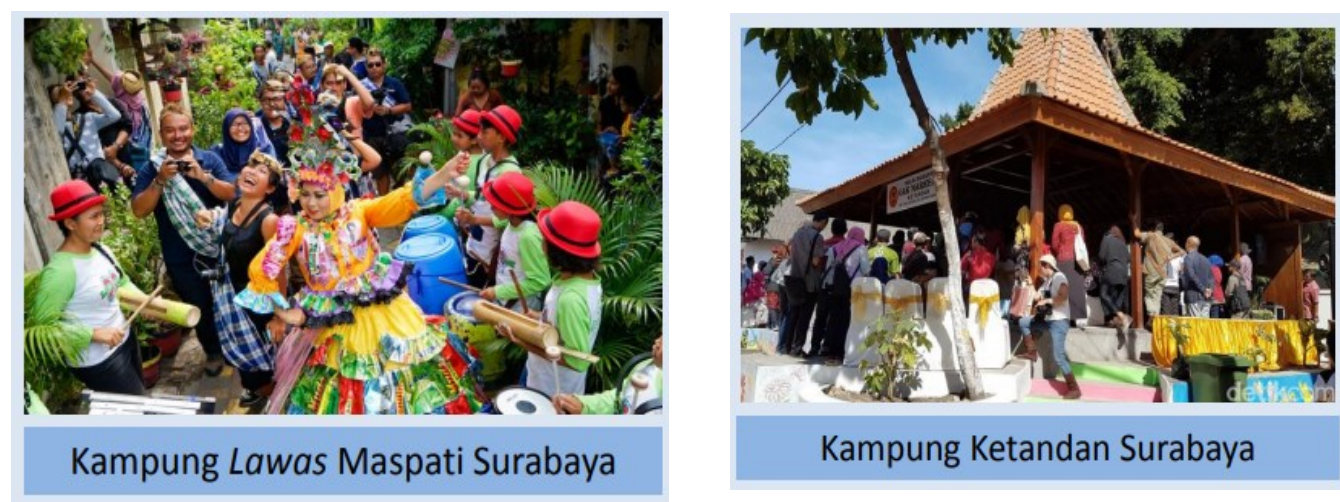

Kampung Ketandan Surabaya
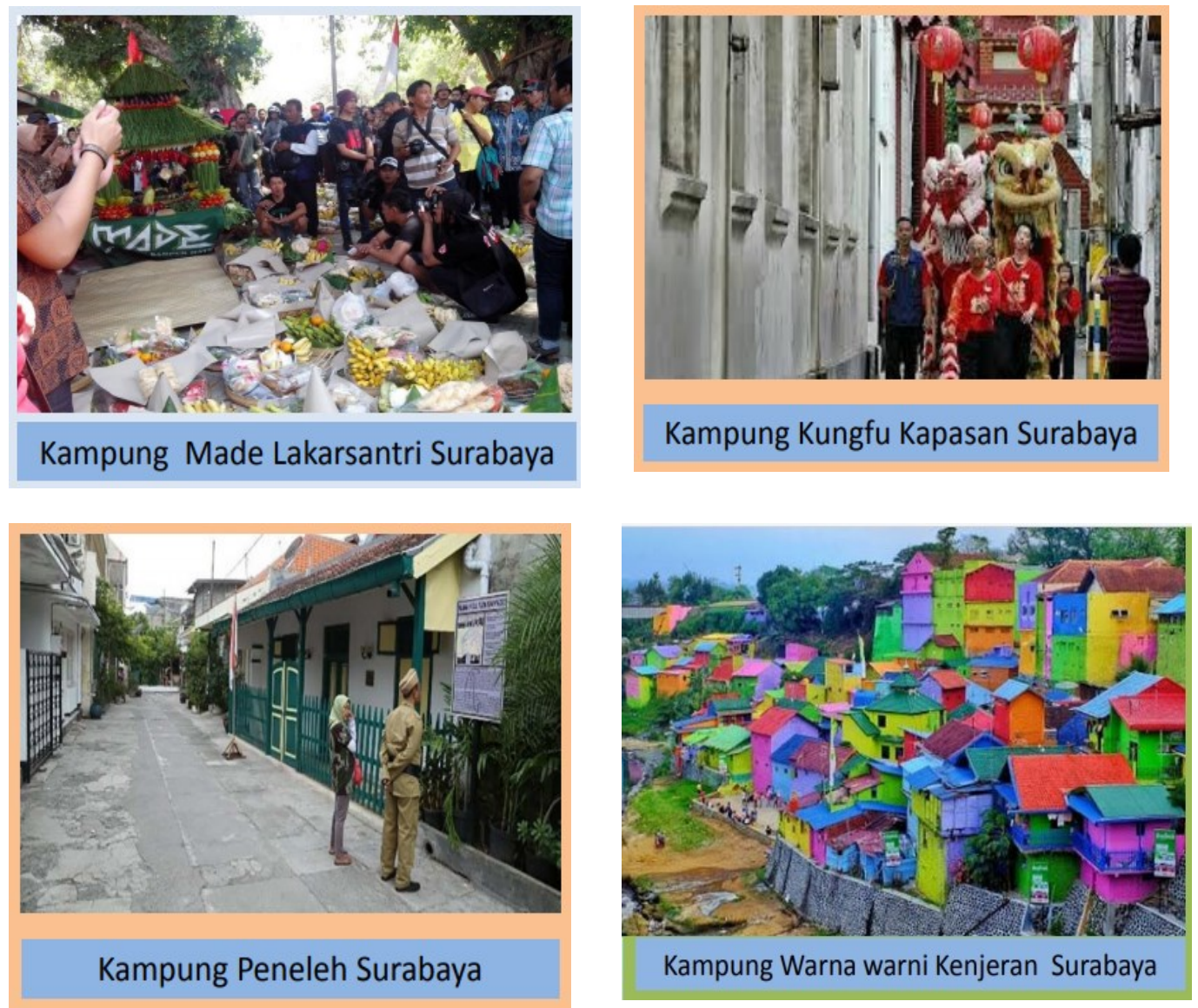

Gambar 1. Beberapa visualisasi kampong kota Surabaya dengan ciri dan identitas masing-masing Sumber: Materi ppt Webinar Inkindo, https://kkp.go.id, (Lesmana, 2020) 


\subsection{Perkembangan Kampung pada Era Pandemi Covid 19}

Adanya pandemic Covid 19 yang terjadi pada era saat ini, tentunya membawa pengaruh yang cukup signifikan pada perkembangan kampong, khususnya kampong-kampong kota di wilayah Surabaya. Dalam hal ini Pemerintah telah menerbitkan berbagai kebijakan terkait dengan adanya protocol kesehatan yang harus dijalankan dalam menghadapi pandemic Covid 19 ini. Beberapa istilah yang banyak ditemui saat ini adalah:

\section{Kampung Tangguh}

Didasari oleh adanya Peraturan dari Wali Kotamadya (Perwali) Surabaya, No 33 Tahun 2020, sebagai perubahan atas Perwali No 28 Tahun 2020 tentang Pedoman Tatanan Normal Baru pada Kondisi Pandemi Covid 19 di Surabaya, maka dibentuklah Kampong Tangguh Wani Jogo Surabaya. Dengan adanya Perwali ini berdampak pada perubahan deliniasi kampong, yakni penentuan batas wilayah kampong. Tujuannya adalah untuk mengontrol kampong sampai pada satuan wilayah terkecil. Selain itu, dengan adanya kebijakan pembentukan Kampong Tangguh Wani Jogo Surabaya, sekaligus dapat melakukan re-definisi (mendefinisikan kembali) arti kampong kota.

Jika pada awalnya mendefinisikan kampung kota, hanya dilihat dari aspek non fisik, yaitu dari nilai social dan kekerabatan dari warga penghuninya saja, maka saat ini mendefinisikan kampung juga bisa dilihat dari aspek fisiknya. Yakni penggunaan istilah kampong bisa didefinisikan dengan adanya wilayah, dimana didalamnya terdapat adanya jalan/ gang yang bersifat micro mobility (hanya dapat dilalui oleh kendaraan roda dua atau tiga).

Adanya kondisi pandemic saat ini, maka deliniasi kampong berubah, secara fisik wilayah bahwa sebuah kampong setara dengan RW (Rukun Warga) yang terdiri dari beberapa RT (Rukun Tetangga). Hal ini ditandai dengan adanya istilah "Wani Jogo Surabaya" yang digerakkan pada satuan wilayah kampong.

\section{Kolaborasi Virtual}

Adanya kondisi pandemic Covid 19 seperti ini, menyebabkan pemerintah mengeluarkan kebijakan tentang Protokol Covid, dimana dampaknya adalah membuat wilayah menjadi terpecah-pecah, tingkat eksklusivitas menjadi lebih tinggi, rasa kepercayaan antar kampong menjadi rendah, karena masyarakat antar kampong satu dengan yang kampong yang lain diharuskan saling menjaga jarak, untuk melindungi diri dan wilayah masing-masing, dari dampak meluasnya pandemic covid 19.

Karenanya untuk mempersatukan dan mempererat hubungan ini, dibutuhkan kolaborasi antar kampong, yang dapat dibentuk secara virtual. Secara psikologis hal ini dapat memberikan rasa keamanan dan kenyamanan perlindungan terhadap situasi pandemic covid 19 yang mencemaskan. Tata langkah, pencegahan dan penanganan dapat diwacanakan secara virtual melalui Blog, Website, maupun Whatsapp, sebagai media komunikasi dan kolaborasi secara virtual.

\section{Lumbung Kampung-Kampung Bergiat}

Istilah lumbung kampong atau lumbung makan kampong, yang dimaksud adalah bahwasanya sebuah kampong harus bergiat untuk melakukan pengadaan bahan pangan/makanan secara mandiri. Dilakukan dengan memanfaatkan halaman/ pekarangan rumah maupun public space lainnya, sebagai media atau area bertanam. Tanaman obat keluarga (Toga), tanaman sayur atau tanaman hidroponik lainnya dapat ditanam untuk menggiatkan urban farming. Diharapkan dengan adanya kegiatan ini minimal hasilnya dapat digunakan untuk memenuhi kebutuhan warga masyarakat sendiri.

\section{Racing Awareness}

Adanya dampak pandemic Covid 19, juga banyak membuat usaha mikro kecil dan menengah (UMKM) yang ada di wilayah kampong kota, menjadi mati suri dan terpuruk. UMKM tidak lagi dapat memasarkan produknya ke luar wilayah (eksternal). Namun kondisi seperti ini dapat dimanfaatkan dengan memasarkan produk UMKM secara internal, dengan memasarkan pada tetangga dekat dalam wilayah kampong. UMKM dapat bersaing dan berkompetisi dengan menjadikan tetangga menjadi target pasar (racing awareness).

Saling melengkapi kebutuhan adalah konsep dasar yang dikembangkan, sehingga hal ini dapat menghidupkan kembali UMKM. Jika pada awalnya bertujuan untuk memenuhi kebutuhan/target pasar di luar wilayah (eksternal), maka saat pandemic covid, dapat dialihkan target pasarnya ke dalam wilayah (internal) dengan mengutamakan pemenuhan kebutuhan antar tetangga sebagai target pasar.

Dampak adanya pandemic Covid ini cukup nyata, pada beberapa kegiatan di kampong kota Surabaya. Upaya kegiatan kampong kota untuk menunjukkan eksistensi dalam menghadapi perkembangan kota, sempat terkendala dengan adanya pandemic Covid ini. Penelitian ini dilakukan dengan tujuan untuk mengkaji wujud atau bentuk kebertahanan dari beberapa kampong kota Surabaya, pada masa pandemic Covid 19. Upaya menyelaraskan kebijakan pemerintah dengan perlakuan dalam era New Normal, perlu dikaji secara 
mendalam, sehingga dapat dianalisa bagaimana implementasi kebijakan tersebut dalam kehidupan seharihari.

\section{Metode}

Penelitian ini termasuk dalam kategori diskriptif kualitatif. Metode pengumpulan data dilakukan dengan mengadakan observasi pada beberapa kampong kota, terkait adanya perubahan perilaku akibat munculnya kebijakan era New Normal, pasca pandemic Covid 19. Beberapa data lapangan juga diperoleh dari hasil indepth interview yang dilakukan secara purposive sampling (Moelong, 1999) pada tokoh masyarakat, pengurus kampong, maupun perwakilan beberapa warga masyarakat. Dari data tersebut selanjutnya dianalisa secara secara diskriptif kualitatif, sehingga diperoleh gambaran, bagaimana implementasi dari kebijakan akibat adanya pandemic Covid 19 tersebut, yang diwujudkan dalam perilaku sehari-hari.

\subsection{Metode Pengumpulan Data}

Guna mempelajari aspek kebertahanan yang dilakukan oleh masyarakat kampong kota, maka menggunakan metode dengan cara melakukan observasi lapangan pada beberapa kampong kota, sebagai sampling untuk mengamati kegiatan warga dalam upaya mempertahankan diri terhadap situasi pandemic. Disamping itu untuk melengkapi data dilakukan wawancara/interview pada beberapa warga masyarakat sebagai responden terpilih (purpose sampling), misalnya dengan Ketua Satgas Kampung Wani Jogo Suroboyo wilayah setempat, yang dibentuk pada beberapa kampong kota, ketua RT atau RW, dan lain sebagainya.

\subsection{Metode Analisis Data}

Dari beberapa gambaran data lapangan selanjutnya didokumentasi, dipelajari dan dianalisis kesesuaiannya antara kebijakan Pemerintah yang tertuang dalam Perwali dengan penerapan/ aplikasi di lapangan, yakni pada kegiatan yang dijalankan pada beberapa kampong kota tersebut. Hasil dari analisa, selanjutnya dikaitkan dengan perilaku atau budaya masyarakat dalam berkegiatan terhadap suatu tempat (place). Disamping itu dilakukan upaya untuk menggali pendapat masyarakat, tentang kondisi yang dirasakan atau dialami sebagai upaya untuk mempertahankan diri terhadap situasi dan kondisi pandemic ini. Sehingga dapat dievaluasi bagaimana implementasi dari kebijakan Pemerintah yang tertuang dalam Perwali tersebut.

\section{Hasil dan Pembahasan}

Dengan adanya pandemic Covid 19 ini telah merubah tatanan perilaku pada masyarakat. Hal inipun telah ditegaskan dan dituangkan dalam kebijakan Perwali Surabaya tahun 2020, yang menjadi landasan untuk dipedomani dalam upaya menjalankan protocol Covid 19, baik untuk warga masyarakatnya maupun lingkungannya. Upaya untuk mempertahankan diri terhadap situasi pandemic Covid 19, tidak hanya menjadi tugas Pemerintah, namun harus didukung oleh seluruh warga masyarakat, khususnya dalam sebuah lingkungan kampong kota.

\subsection{Pembentukan Kampung Tangguh Wani Jogo Suroboyo}

Pembentukan kampong tangguh, merupakan gerakan untuk melindungi warga masyarakat dan lingkungan kampungnya dari meluasnya pandemic Covid 19, dengan cara melakukan screening (penggunaan masker, pencucian tangan dan penggunaan hand sanitizer, pengecekan suhu tubuh serta penyemprotan) terhadap warga masyarakat yang keluar masuk pada sebuah wilayah tertentu. Akses keluar masuk dibatasi dan dijaga oleh petugas dengan menerapkan protocol Covid 19 tersebut. Pembetukan satuan tugas (Satgas) ini dikoordinir dibawah pengawasan RT (Rukun Tetangga) dan RW (Rukun Warga). Adanya satgas ini akan memudahkan control dan pengawasan terhadap keluar masuknya seseorang pada wilayah tertentu.

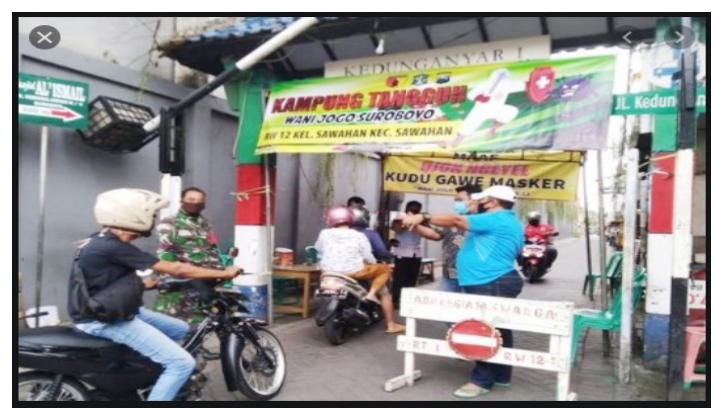

Gambar 2. Penerapan Protokol Covid 19 pada pintu masuk kampong kota Surabaya Sumber: Patrolipost.com (2020) 
Istilah Wani Jogo Suroboyo, merupakan sebuah istilah yang melekat pada Kampung Tangguh. Upaya ini dilakukan guna memutus rantai penyebaran dan penularan virus Covid 19. Dalam mewujudkan sebuah kampong tangguh, maka seluruh warga masyarakat bersepakat dan bersatu dengan komitmen untuk berani menjaga Surabaya kota tercinta dari meluasnya penyebaran virus. Menumbuhkan kesadaran warga akan bahaya Covid 19, sehingga warga semakin sadar untuk tidak keluar rumah jika tidak penting, dan selalu menggunakan masker dan mencuci tangan. Adanya kegiatan ini ternyata membawa manfaat yang sangat baik, yakni menumbuhkan keguyuban dan kegotong-royongan antar warga (Lesmana et all, 2020). Kegiatan ini ternyata juga dapat memberikan kontribusi pada perasaan keterkaitan manusia terhadap tempatnya (Prijotomo dan Pangarsa, 2010).

\subsection{Terbentuknya Colaboration Virtual}

Adanya himbauan untuk tidak keluar rumah/ berdiam di rumah (stay at home), dan selalu menjaga jarak, merupakan salah satu diantara banyak protocol covid lainnya, yang membawa dampak dan perubahan yang cukup besar bagi keberlangsungan komunikasi antar warga baik secara internal (dalam kampong) maupun eksternal (luar kampong). Sehingga jalur komunikasi yang dianggap paling efektif adalah menggunakan virtual (dunia maya).

Upaya mempromosikan kampong dengan segala keunikannya telah banyak dilakukan warga, sambil menggelar berbagai atraksi yang menarik dan layak jual. Sehingga masyarakat dari luar kampong berbondong-bondong untuk datang dan menikmati suasana kampong. Namun semenjak adanya pandemic Covid 19, kegiatan seperti ini berhenti total. Banyak warga kehilangan kegiatan sampingannya, karena upaya untuk mempromosikan kampong manjadi terhambat.

Disisi lain, upaya untuk mengkampanyekan protocol Covid agar mudah dipahami, diingat dan dipraktekkan oleh banyak orang, maka dibutuhkan visualisasi yang dapat diakses dan dilihat banyak orang. Sehingga akan menjadi pengingat jika dilihat secara terus menerus. Karenanya dibutuhkan media komunikasi untuk mengkolaborasikan secara virtual, pada setiap rekaman kegiatan. Media ini dapat dibuat dalam bentuk blog, website, maupun whatsapp. Hal ini menjadi cara ampuh yang dapat dilakukan, karena setiap warga dapat dengan mudah untuk mengakses dan menikmati sajian maupun tampilan yang ditayangkan lewat media ini, tanpa harus keluar rumah dan berkumpul beramai-ramai. Kegiatan dan promosi kampong kota dapat dieksplorasi melalui tayangan di Blog maupun Website, sedangkan untuk komunikasi yang lebih intens dan privacy dapat dilakukan melalui whatsapp, baik secara personal maupun group. Kabar dan informasi penting perihal Covid maupun lainnya dapat disebar secara cepat, sehingga tindakan antisipatif dapat lebih cepat dilakukan.

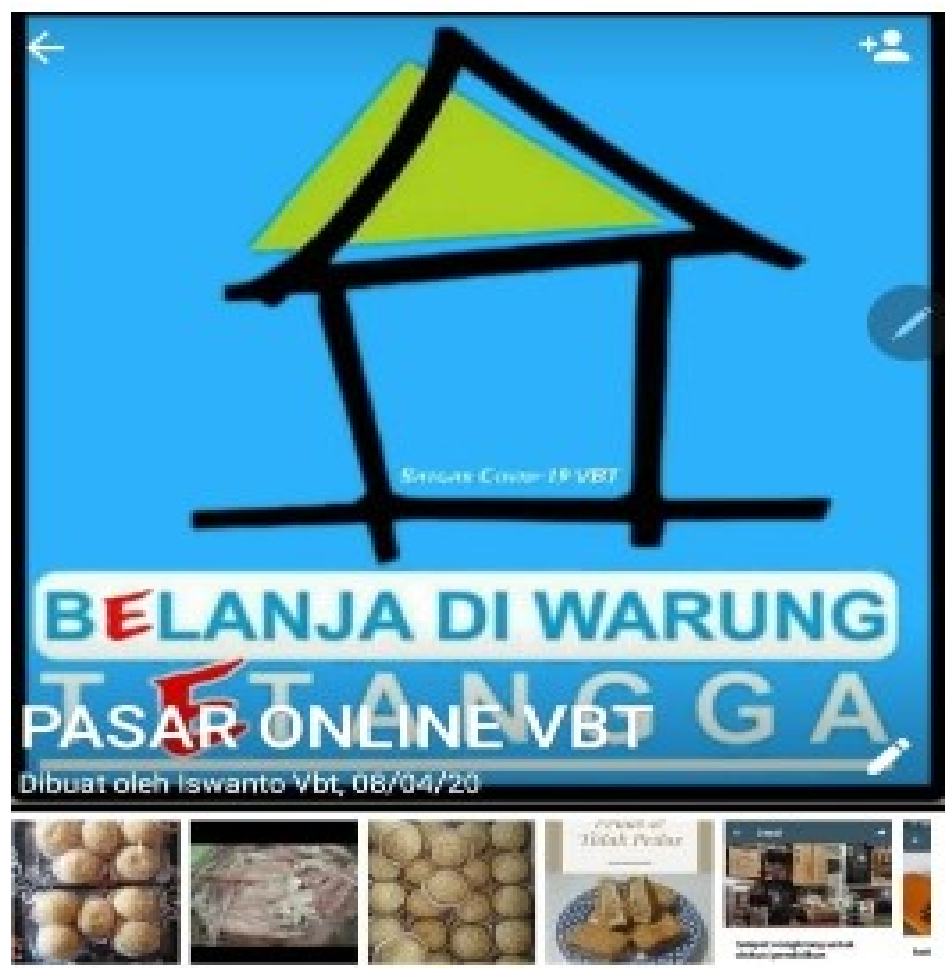

Gambar 3. Menggerakkan ekonomi warga melalui penjualan online Sumber: seru.co.id (2020) 


\subsection{Menggalakkan Lumbung Kampong-Kampung Bergiat}

Lumbung Kampung merupakan lembaga cadangan pangan di daerah perkampungan yang berperan untuk mengatasi kerawanan pangan masyarakat (Adriono, 2020). Kegiatan dalam lumbung kampong adalah penyediaan sembako murah atau gratis, yang disubsidi oleh Pemerintah. Tujuannya adalah membantu masyarakat yang tingkat kesejahteraannya menurun, akibat terkena dampak Covid, sehingga.

Upaya kampong bergiat, ditandai dengan adanya upaya untuk memenuhi kebutuhan sehari-hari yang berasal dari lingkungan sekitar. Aspek lingkungan sekitar, dalam hal ini pekarangan rumah, menjadi salah satu sudut yang penting dalam mendukung terciptanya lingkungan hijau yang asri. Sebagian besar warga masyarakat kampong kota, tidak mempunyai halaman yang cukup luas untuk bertanam atau berkebun. Karenanya, banyak warga mulai memanfaatkan pekarangan rumah untuk ditanami dengan berbagai tanaman rempah dan obat-obatan, guna mendukung kebutuhan sehari-hari, seperti: kunyit, laos, jahe, sereh, daun bawang, cabe, tomat, kemangi, daun sirih dan tanaman perdu lainnya. Serta berbagai pepohonan, yang tidak terlalu besar dahannya, seperti belimbing sayur, belimbing buah, jeruk nipis, pepaya, dan lain sebagainya. Dengan sempitnya lahan, menimbulkan berbagai kreasi dalam menata lingkungannya, baik dengan pola tanaman gantung, tanaman merambat, maupun tanaman berbunga lainnya, sehingga terlihat asri dan menambah keindahan lingkungan sekitarnya. Kampung Genteng Candirejo, merupakan salah satu kampong yang berhasil membentuk ikon sebagai "Kampung Herbal", karena adanya aktifitas UMKM yang menghasilkan minuman herbal.

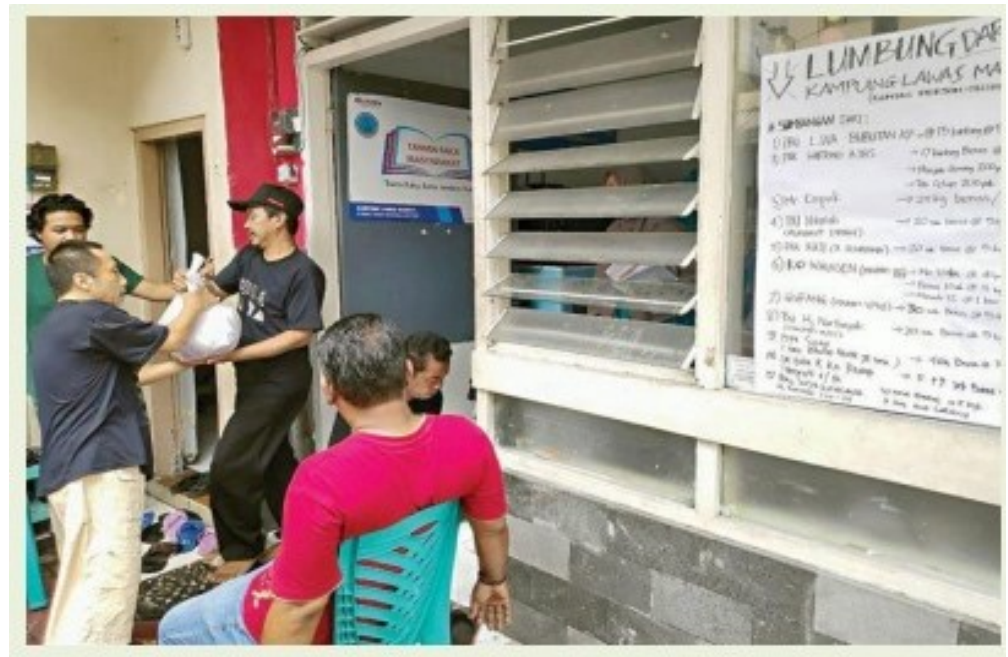

Gambar 4. Kegiatan Kampung Lumbung berupa bantuan sembako di Kampung Maspati Surabaya Sumber: Lesmana (2020)

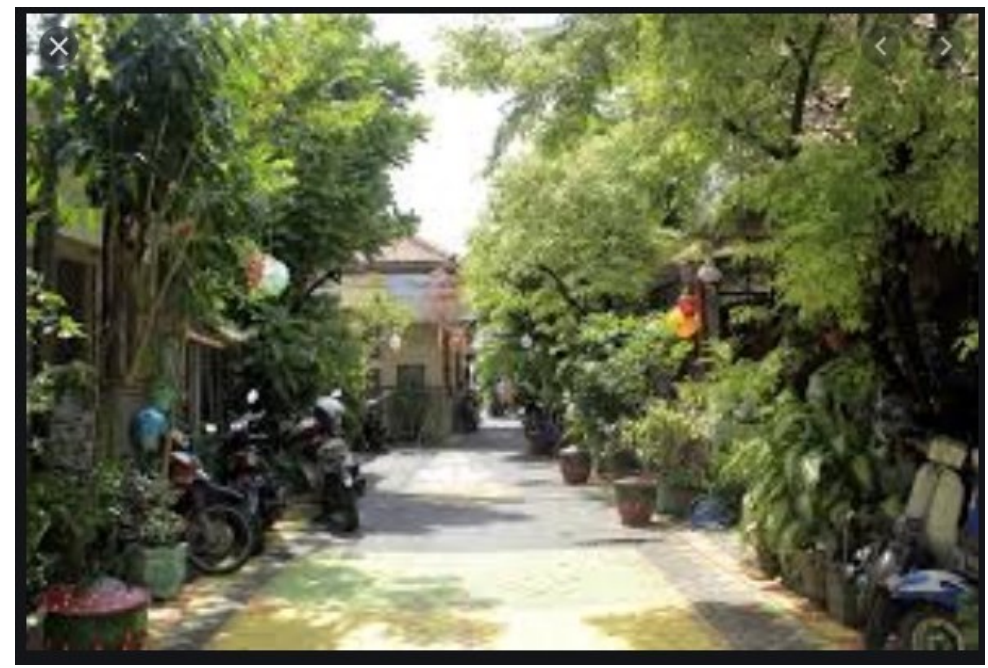

Gambar 5. Kampung bergiat di Genteng Candirejo, menghasilkan ikon sebagai "Kampung Herbal" Sumber: ramadhanisa.co.id (2020) 


\subsection{Menumbuhkan Kepedulian (Racing Awareness)}

Himbauan untuk tidak keluar rumah, merupakan salah satu langkah antisipatif untuk memutus rantai penyebaran covid 19, karena dikhawatirkan akan terbentuk klaster-klaster baru dari kerumunan banyak orang. Hal ini memberikan dampak yang cukup signifikan bagi pedagang makanan atau warga masyarakat yang mempunyai usaha sampingan di bidang kuliner, dengan menurunnya omzet penjualan. Jika pada kondisi sebelum adanya wabah pandemic covid 19, warga masyarakat banyak yang menjajakan kuliner sampai di luar wilayah kampong, maka pada saat pandemic seperti ini, kegiatan seakan berhenti.

Untuk menggiatkan kembali usaha sampingan di bidang kuliner, maka warga masyarakat mencoba menawarkan kepada lingkungan terdekatnya, yakni tetangga di sekitar rumah dengan harga terjangkau. Bak gayung bersambut, antar tetangga dapat menjalin kesepakatan untuk saling memenuhi kebutuhan dengan cara menyiapkan menu kuliner yang berbeda jenisnya, sehingga dapat saling melengkapi satu dengan lainnya. Hal ini tentu saja menimbulkan rasa kebersamaan dan kekeluargaan yang sangat erat. Yang berkelebihan dapat membantu yang kekurangan, baik berupa bahan makanan yang belum diolah maupun berupa lauk dan sayur-mayur yang sudah diolah. Rasa simpati dan empati mulai muncul, terutama bagi warga yang terdampak Covid, sehingga memunculkan ide semangat berbagi di tengah pandemic dengan "Sedekah Sayur" seperti gambar berikut ini.

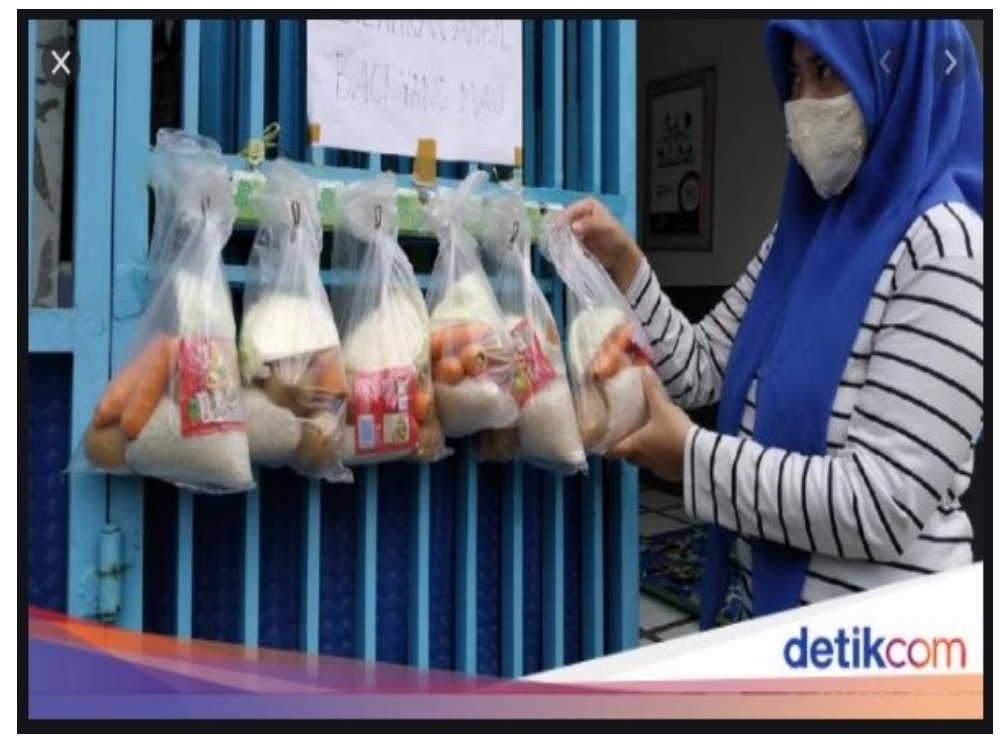

Gambar 6. Upaya membantu Warga yang terdampak Covid, dengan "Sedekah Sayur" Sumber: newsdetik.com (2020)

\section{Kesimpulan}

Adanya pandemic Covid 19 ini membawa perubahan yang cukup besar pengaruhnya pada masyarakat. Perubahan perilaku dengan tatanan baru, keterpurukan kondisi ekonomi karena menurunnya daya beli, hampir dirasakan sebagian besar masyarakat, termasuk warga kampong kota Surabaya. Hasil dari penelitian ini memberikan kesimpulan bahwa kebertahanan dalam menghadapi pandemic Covid 19 ini, bermuara dari adanya kebijakan dalam penanganan pandemic covid 19 sebagai langkah antisipatif mencegah meluasnya penularan. Diwujudkan dengan pembentukan satuan gugus tugas, yang membawa pengaruh fisik lingkungan kampong dan psikologis warga masyarakat.

Kebertahanan secara fisik ditandai dengan meningkatnya kualitas ruang luar halaman kampong, menjadi lebih asri dan lebih tertib dengan menerapkan protokoler Covid. Sedangkan kebertahanan secara non fisik (psikologis), adalah adanya rasa kebersamaan yang kuat untuk melindungi teritori wilayah kampong. Tumbuhnya keguyuban dan kegotong-royongan warga untuk saling menjaga lingkungan, timbulnya rasa simpati dan empati untuk saling berbagi terhadap sesama. Kolaborasi dari kedua aspek ini menimbulkan rasa memiliki terhadap tempat (sense of place) menjadi sangat kuat.

\section{Ucapan Terima Kasih}

Ungkapan terima kasih, disampaikan kepada ibu Retno Hastijanti, selaku nara sumber utama pada penelitian ini, sekaligus sebagai Ketua Tim Ahli Bangunan Cagar Budaya Kota Surabaya. Ungkapan terima kasih juga dihaturkan kepada DPP Inkindo Jawa Timur, selaku penggerak adanya ide gagasan penelitian, serta pihak lain yang tidak bisa disebut satu persatu, yang telah banyak membantu dan berkontribusi demi terwujudnya artikel penelitian ini. 


\section{Daftar Pustaka}

Adriono, 2020, “Menyiapkan Tata Ruang Pasca Pandemi”, Media Konsultan Inkindo, Nomor ISSN: 2549-5984 Tahun ke 5 Volume 2, Inkindo Jawa Timur.

Hastijanti, Retno, 2020, “Kondisi Kampung Kota Surabaya di Masa Pandemi”, Ketua TABCB Kota Surabaya.

IDN Times, 2019, "Lima Kampung Paling Unik di Surabaya", ramadhannisa.co.id

Lesmana, 2020, Webinar INKINDO, “Kebertahanan Masyarakat Kampung Kota Pasca Pandemi 19”, https://kkp.go.id

Lesmana, et all, 2020, "Sense of Place in Lawas Maspati Village Community at Surabaya: Exploration Study Towards Physical. Social, and Cultural Factors". ARTEKS: Jurnal Teknik Arsitektur, 6 (1), Universitas

Moelong L.J, 1999, "Metodologi Penelitian Kualitatif”, Bandung, Remaja Rosdakarya.

Peraturan Wali Kotamadya (Perwali) Surabaya, No 28 Tahun 2020, tentang Pedoman Tatanan Normal Baru Pada Kondisi Pandemi Corona Virus Disease 2019 (Covid-19) Di Kota Surabaya.

Peraturan Wali Kotamadya (Perwali) Surabaya, No 33 Tahun 2020, tentang Perubahan Atas Peraturan Walikota Surabaya Nomor 28 Tahun 2020 tentang Pedoman Tatanan Normal Baru Pada Kondisi Pandemi Corona Virus Disease 2019 (Covid 19) Di Kota Surabaya.

Prijotomo, Pangarsa, 2010, Rong: Wacana Ruang Arsitektur Jawa, Ebook Enginee, wwwruangarsitektur.com 